\title{
INFLUENCE OF STEAM-SIDE OXIDE SCALES ON THE CREEP LIFE OF A BOILER SUPERHEATER TUBE
}

\author{
VPLIV ŠKAJE NA PARNI STRANI CEVI IZMENJEVALNIKA \\ TOPLOTE NA DOBO TRAJANJA CEVI ZARADI LEZENJA
}

\author{
Martin Nad', Tomáš Létal, Jiří Buzík, Pavel Lošák \\ Brno University of Technology, Faculty of Mechanical Engineering, Institute of Process Engineering, Technicka 2, 616 69 Brno, \\ Czech Republic \\ nad@fme.vutbr.cz
}

Prejem rokopisa - received: 2017-07-05; sprejem za objavo - accepted for publication: 2017-09-22

doi:10.17222/mit.2017.106

Creep life is a limiting factor in the case of boiler tubes operating above the creep temperature and, for a given material, it is generally determined by the actual operating temperature and stress. Standard approaches to the calculation of a tube creep life mainly take into account the stress caused by pressure loading and the mean temperature in the tube wall. However, the estimation of the temperature and stress may be difficult for water-tube boilers because oxide scales tend to form on the inner surfaces of the tubes, exposed to steam and indirectly affecting the resulting creep life. As the scales increase the thermal resistance of a tube wall and, consequently, the wall temperature, the creep life is reduced. Moreover, the presence of oxide scales leads to a higher hydraulic resistance of a tube, which can cause further increase in the temperature in some tubes of the bundle if the oxide-scale growth rate is not uniform. Additionally, the elements increasing the creep strength may leach out of the surface should the scales be porous, thus inducing an even more pronounced decrease in the creep life. This paper investigates the effects of oxide scales on the creep life of boiler tubes in a cross flow. Thermal and stress conditions in the tubes are thoroughly investigated, using analytical as well as numerical approaches.

Keywords: oxide scale, creep, superheater, tube, CFD, FEA

Doba trajanja cevi super izmenjevalnikov toplote je omejena zaradi lezenja materiala pri visokih temperaturah obratovanja. Kritična temperatura lezenja je odvisna od napetosti, ki nastopajo med obratovanjem izmenjevalnika toplote. Standardni pristop za izračun dobe trajanja zaradi lezenja materiala temelji na upoštevanju napetosti, ki jih povzroča delovni tlak prenasičene pare in povprečne temperature na stenah cevi. Vendar je temperaturo in napetosti težko oceniti, ker se na notranjih stenah cevi, ki so izpostavljene pari, nalaga oksidna plast oz. škaja, kar neposredno vpliva na njihovo dobo trajanja. Škaja na stenah cevi zmanjša toplotno prevodnost in $\mathrm{s}$ tem poslabša prenos toplote in posledično spremeni temperaturo sten cevi, kar zmanjša njihovo dobo trajanja. Poleg tega škaja poveča hidravlično upornost cevi, ki nadalje poviša temperaturo v nekaterih snopih cevi, če rast škaje ni enkomerna. Dodatno se lahko iz sten cevi zaradi škaje izlužijo legirni elementi, ki povečujejo odpornost materiala proti lezenju. To lahko povzroči poroznost oksidne plasti na ceveh, kar še dodatno zmanjša njihovo dobo trajanja. V članku avtorji obravnavajo vpliv oksidne škaje na življensko dobo cevi izmenjevalnikov toplote $\mathrm{v}$ toku ogrevalnih plinov prečno na pretok pare. Analizirali so termične in napetostne razmere v ceveh izmenjevalnika toplote $\mathrm{z}$ analitičnimi in numeričnimi metodami.

Ključne besede: škaja (oksidna plast), lezenje, super izmenjevalnik toplote, cevi izmenjevalnika, računalniška dinamika fluidov (CFD), analiza z metodo končnih elementov (FEA)

\section{INTRODUCTION}

Boiler-design life expectancy is usually in tens of years and it is impossible to predict the exact operating conditions for such a long time; therefore, various kinds of damage must be expected. Although particular damage mechanisms are intertwined and rarely occur individually, they may be categorized according to primary causes: ${ }^{1,2}$

- temperature

- corrosion

- fluid flow

- operation

- manufacturing and installation

During manufacturing, different materials may be selected. This error was also identified during the investigation of the boiler-tube damage where, instead of high-grade 15020 steel, low-grade 12022.1 steel was used, which was found out with a material analysis. ${ }^{3}$

The 15020 steel exhibits a high-temperature corrosion resistance up to $530{ }^{\circ} \mathrm{C}$ in a steam environment, which makes it suitable for superheater tubes. ${ }^{4}$ On the other hand, the 12022.1 steel just guarantees yield strength at elevated temperatures and it is suitable for basic piping and pressure vessels. ${ }^{5}$

\subsection{Creep behaviour of steel}

Creep is often considered as the limiting factor for the boiler tubes exposed to high temperatures. There are efforts to increase operating temperatures as they would increase the boiler efficiency. However, this increase may considerably decrease the life of exposed components; therefore, it is important to assess the effect of an increased temperature. 
This assessment can be performed thorough a transient-creep simulation using a FEA (finite-element analysis) that takes into account the creep-material model as well as the history of operation conditions. As this approach would be time consuming, simplified methods are preferred when applicable.

According to many standards, the ultimate tensile strength of a steel at a given temperature is guaranteed only for a limited time. When a tube is exposed to temperature and stress for a given time, the creep life reduction can be estimated according to the procedure in standard EN 12952-4. ${ }^{6}$

\section{THERMAL ANALYSES}

Since the creep behaviour of steels is strongly affected by the temperature, a thorough thermal analysis of tubes made of steel 12022.1 was performed. A tube from the first row of the superheater was selected as the most exposed. The tube cross-section was TR $38 \times 5.6$ and the dimensions as well as tolerances were set according to standard ČSN $426710 .^{7}$

The temperatures in the tube wall were between the flue-gas temperature and steam temperature and it depended on several factors:

- thermal conductivity and thickness of the steel;

- thermal conductivity and thickness of the oxide scale;

- flue-gas velocity distribution around the tube, its temperature and other properties;

- steam temperature and velocity in the tube.

Temperature distribution was investigated using a 2D model of the tube wall. Heat-transfer coefficients were estimated using a 2D CFD analysis of the cross flow at the flue-gas side and empiric calculations at the steam side.

\subsection{Heat-transfer coefficient at the steam side}

The heat-transfer coefficient was assumed to be constant across the circumference of the tube inner surface. At the investigated spot, there was steam at a temperature of $369^{\circ} \mathrm{C}$ and a pressure of $3.56 \mathrm{MPa}$. The steam with a velocity of $11.7 \mathrm{~m} / \mathrm{s}$ was in a turbulent regime $(\operatorname{Re} \sim 170000)$. The values were taken from operational records.

The heat-transfer coefficient was calculated using a formula based on the Nusselt number:

$$
\alpha=\frac{N u \cdot \lambda}{d_{\text {in }}}
$$

where:

$\alpha$ heat-transfer coefficient

$N_{\mathrm{u}}$ Nusselt number

$\lambda$ thermal conductivity

$d_{\text {in }}$ internal tube diameter

The Nusselt number was estimated using the Gnielsinsky formula (Equation (2) from ${ }^{8}$ for the tube side:

$$
\begin{aligned}
& N u=\frac{\left(\frac{\xi}{8}\right) \cdot \operatorname{Re} \cdot \operatorname{Pr}}{1+12.7 \cdot \sqrt{\frac{\xi}{8} \cdot\left(\operatorname{Pr}^{2 / 3}-1\right)}} \cdot\left[1+\left(\frac{d_{\text {in }}}{l_{\text {tr }}}\right)^{2 / 3}\right] \\
& \xi=(1.8 \cdot \lg \operatorname{Re}-1.5)^{-2}
\end{aligned}
$$

where:

Re Reynolds number

$P r$ Prandtl number

$d_{\text {in }}$ internal tube diameter

$l_{\text {tr }}$ tube length

The final value of the heat-transfer coefficient at the inner wall of the tube was $709.69 \mathrm{~W} /\left(\mathrm{m}^{2} \cdot \mathrm{K}\right)$.

\subsection{Heat-transfer coefficient at the flue-gas side}

The heat-transfer coefficient at the flue-gas side was assumed to be a function of the angle around the tube due to cross-flow effects. Distribution of the coefficient was estimated using a simplified 2D CFD analysis that was designed to accurately describe von Karman vortices. Figure 1 shows dimensions of the simulated domain as well as the location of the boundary conditions used. ${ }^{9}$ A mesh with 41302 elements was created and its quality is described in Table $\mathbf{1 .}$

Table 1: CFD mesh quality

\begin{tabular}{|c|c|c|c|}
\hline & Min & Max & Average \\
\hline Element quality & 0.47 & 1 & 0.99 \\
\hline Aspect ratio & 1 & 1.95 & 1.03 \\
\hline Skeweness & $1.31 \mathrm{e}-10$ & 0.56 & $1.49 \mathrm{e}-2$ \\
\hline Orthogonal quality & 0.68 & 1 & 0.99 \\
\hline
\end{tabular}

The heat-transfer-coefficient distribution obtained from the CFD analysis takes into account only convection. However, radiation also plays an important role in this case..$^{10}$ The radiation influence was estimated from thermal-hydraulic calculations and it was added, as a constant value of $15.9 \mathrm{~W} /\left(\mathrm{m}^{2} \mathrm{~K}\right)$ across the tube circumference, to the convection-heat-transfer-coefficient distribution from the CFD analysis.

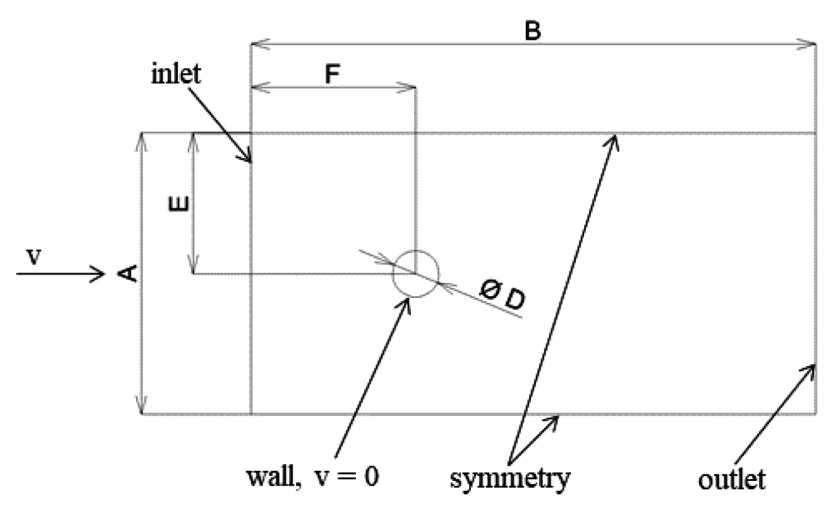

Figure 1: CFD analysis of flue-gas-flow-simulation boundary conditions $(\mathrm{A}=20 \cdot \mathrm{D}, \mathrm{B}=3 \cdot \mathrm{D}, \mathrm{E}=10 \cdot \mathrm{D}, \mathrm{F}=12.5 \cdot \mathrm{D})$ 


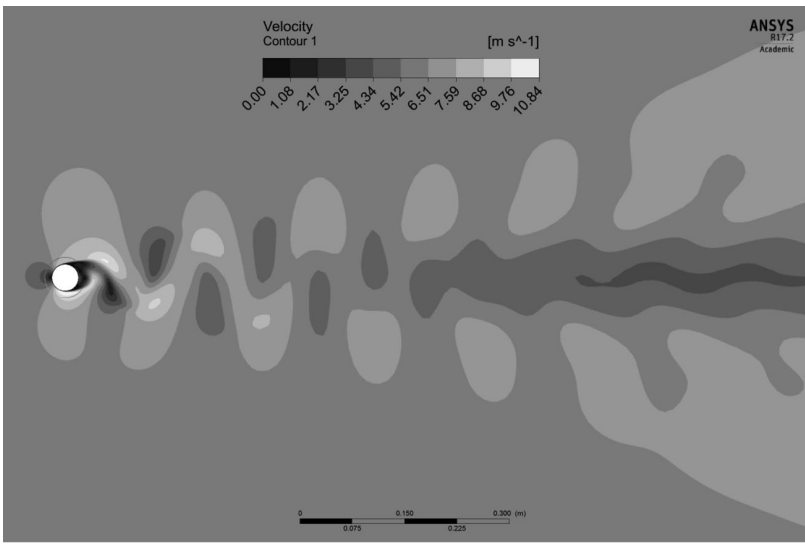

Figure 2: Flue-gas velocity around the investigated tube

The vortices are apparent from the CFD simulation, which was interrupted only after a steady vortex formation was established. Results from the transient CFD simulation for the last $0.0272 \mathrm{~s}$, which corresponds to the lifetime of one vortex, were processed. Using this approach, the whole periodic cycle of the cross flow was very accurately described.

The resulting overall heat-transfer-coefficient distributions as well as symmetrical mean distribution are shown in Figure 3. It shows that the highest mean value of the heat-transfer coefficient is on the left side of the tube where hot flue gasses have the biggest influence. On the other side of the tube, the heat-transfer coefficient is much lower because of the formation of vortices.

\subsection{Tube temperature distribution}

Probably due to the change of the material, there was already an oxide scale on the inner surface of the investigated tube after $62,000 \mathrm{~h}$ of the operation as determined with a metallurgical analysis. ${ }^{3}$ Since oxide has a lower thermal conductivity than steel, higher mean tempera-

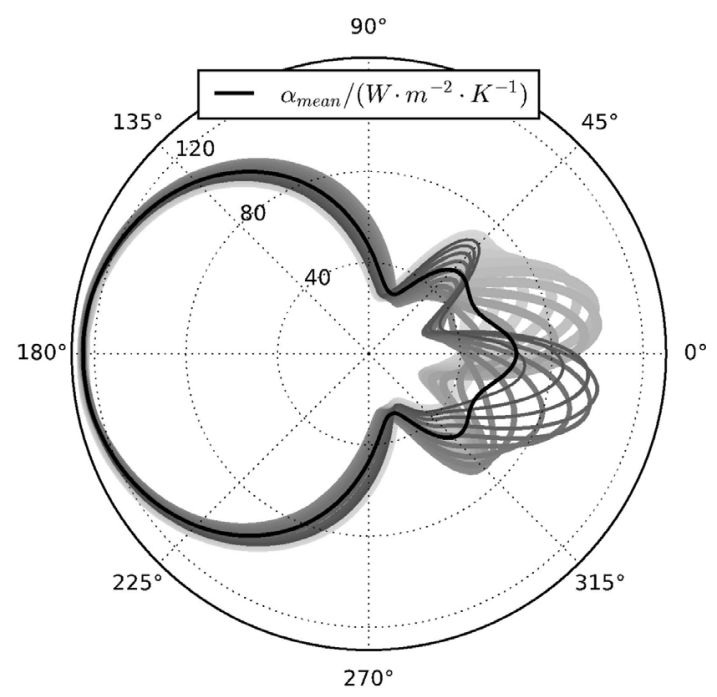

Figure 3: Overall heat-transfer-coefficient distributions across the tube circumference at time points (grey) and the symmetrical mean value (black)



Figure 4: Temperature-distribution comparison for the tube crosssections: with oxide scale on the internal surface (top half) and without oxide scale (bottom half)

tures and a resulting decrease in the creep life may be expected.

The oxide scale composed of $\mathrm{Fe}_{3} \mathrm{O}_{4}$ that was included in the FEA simulation has a thickness of $0.5 \mathrm{~mm}$ and its material properties were taken from ${ }^{11,12}$.

The resulting temperature distributions for the two cases are shown in Figure 4. As can be seen, the material temperature is a bit higher where the oxide scale occurs (the top half), which may influence the tube life. For the creep assessment in the next section, maximum temperatures along the circumference (obtained from the FEA simulation) are used. A comparison of the meantemperature distributions across the circumference is shown in Figure 5.

\section{TUBE CREEP-LIFE ESTIMATION}

An uneven through-wall stress distribution may change due to a creep process; therefore, the membrane stress is considered to be the most significant factor influencing the creep life. The calculated temperature is conservatively considered as the maximum value thorough the wall, which is $433.86{ }^{\circ} \mathrm{C}$ for the tube without oxide scale and $438.54{ }^{\circ} \mathrm{C}$ for tube with oxide scale.

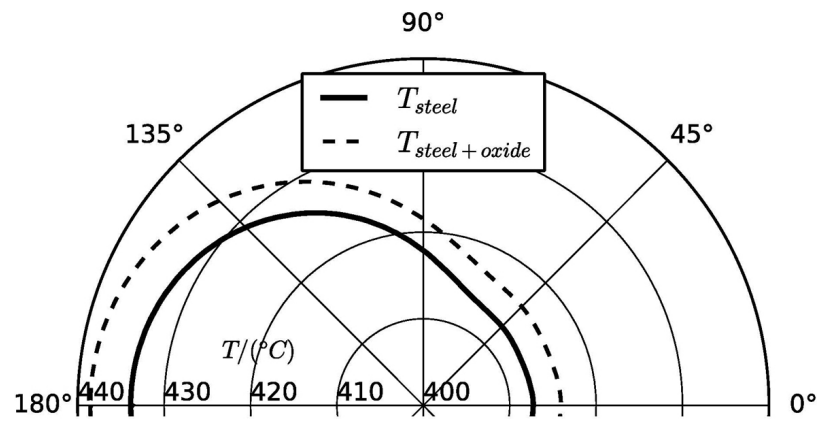

Figure 5: Maximum wall-temperature distributions: steel only (solid line), steel with oxide scale (dashed line) tube creep-life estimation 


\subsection{Stress estimation}

The membrane stress intensity in the tube wall is driven by the pressure and it can be calculated using formula (3) derived from ${ }^{13}$ :

$$
f_{o p}=\frac{p_{\mathrm{c}}\left(d_{\mathrm{os}}-2 e_{\mathrm{cs}}+v e_{\mathrm{cs}}\right)}{2 v e_{\mathrm{cs}}}
$$

where:

$p_{\mathrm{c}}$ calculation pressure

$d_{\text {os }}$ external tube diameter

$e_{\mathrm{cs}}$ tube thickness

$v$ thinning coefficient

Calculated stress intensity $f_{\text {op }}$ in the tube is 10.605 MPa.

\subsection{Influence of the material characteristics}

As shown in Figure 5, the maximum temperatures are in ranges of $412-434{ }^{\circ} \mathrm{C}$ and $415-438{ }^{\circ} \mathrm{C}$ for steel and steel with oxide scale, respectively. The creep temperature range of the 15020 steel starts at $450{ }^{\circ} \mathrm{C}$, therefore, without a change of the material, the creep would be of no concern. The current material - the 12022 steel - is in the creep mode, starting at $380{ }^{\circ} \mathrm{C}$; therefore, the creep must be checked.

\subsection{Remaining creep life}

An estimation of the remaining creep life was performed using the procedure from standard EN 12952-4. ${ }^{6}$ Its results can be seen in Figure 6. Due to the low stress intensity, the creep life of $9.64 \mathrm{e} 8 \mathrm{~h}$ and $3.65 \mathrm{e} 8 \mathrm{~h}$ for pure steel and the steel with oxide scale, respectively, well exceeds the design life of the boiler. However, as continuous thinning of the tube wall, due to corrosion and erosion, increases the stress intensity, it can be expected that the creep life will be significantly reduced.

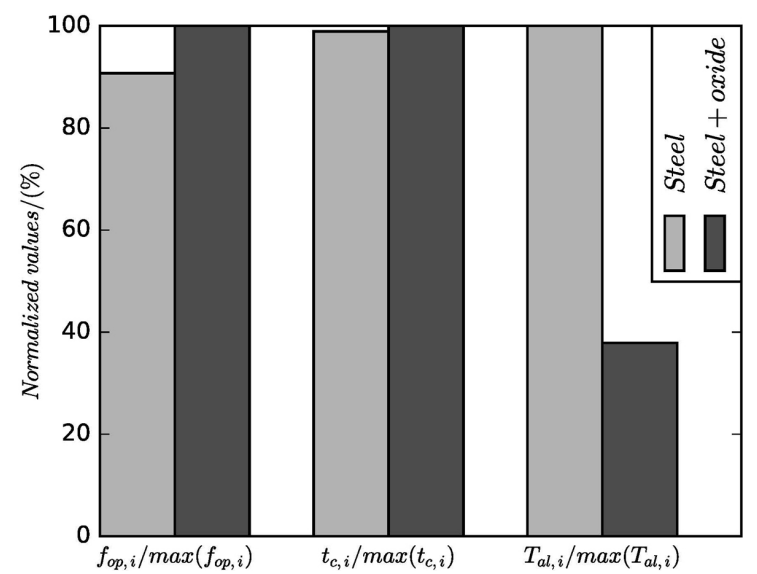

Figure 6: Relative comparisons of stress intensities, temperatures and creep lives for pure steel and steel with oxide scale $\left(f_{\text {op }}-\right.$ membrane stress at operating conditions, $t_{\mathrm{c}}-$ mean temperature, $T_{\mathrm{al}}-$ time to reach the theoretical rupture by creep)

\section{CONCLUSIONS}

Heat-transfer tubes in water-tube boilers are exposed to high pressures and temperatures. Oxide scales forming on the inner surface of a superheater tube may increase the tube temperature. In addition, the accompanying reduction in the tube thickness leads to an increase in the membrane stress induced by pressure. Even in the case where these changes are slight, a combined effect on the creep life can still be significant as shown in Figure 6.

In the cross-flow arrangement, there is unequal distribution of the temperature along the tube circumference. This factor should be considered in creep-life estimations due to creep's sensitivity to temperature. CFD and FEA analyses may be required for an accurate estimation of the temperature distribution.

\section{Acknowledgement}

The outcomes of project NETME CENTRE PLUS (LO1202) were co-funded by the Ministry of Education, Youth and Sports within the support programme "National Sustainability Programme I".

\section{REFERENCES}

${ }^{1}$ D. J. Flynn, R. D. Port, Nalco Chemical Company, The nalco guide to boiler failure analysis, 2 nd ed., New York: McGraw-Hill, 2011, 599

${ }^{2}$ M. Asgaryan, N. Simms, S. M. Wu, Prediction of the Remaining Service Life of Superheater and Reheater Tubes in Coal-Biomass Fired Power Plants, Adv. Mater. Res., 856 (2014), 343-8

${ }^{3}$ J. Štemberk, M. Halaš, Diagnostic inspection of boiler pressure system, NDT servis s.r.o., May 2011, Report No. NDT/419/2011

${ }^{4}$ CSN 415020 - Steel 15020 molybdenum alloy, Prague, Czech republic, 1981, 12

${ }^{5}$ ČSN 412022 - Steel 15 022, Prague, Czech republic, 1987, 8

${ }^{6}$ European standard: EN 12952-4 Water-tube boilers and auxiliary installations - Part 4: In-service boiler life expectancy calculations, September 2011, AFNOR

${ }^{7}$ ĆSN 426710 - Tubes seamless cold formed with conventional deviations from grades 11 to 16, Prague, Czech republic, 1979, 8

${ }^{8}$ Verein Deutscher Ingenieure, VDI heat atlas, 2nd ed., Heidelberg: Springer, 2010, 1585 p. (Springer reference)

${ }^{9}$ J. Buzík, T. Létal, Comparison of force responses in a tube bundle under different boundary conditions, 2015

${ }^{10}$ Z. Jegla, J. Vondál, J. Hájek, Standards for fired heater design: An assessment based on computational modelling, Appl. Therm. Eng., 89 (Supplement C) (2015), 1068-78

${ }^{11}$ M. Takeda, T. Onishi, S. Nakakubo, S. Fujimoto, Physical Properties of Iron-Oxide Scales on Si-Containing Steels at High Temperature, Mater. Trans., 50 (2009) 9, 2242-6

${ }^{12}$ Mechanical properties of magnetite (Fe3O4), hematite (á-Fe2O3) and goethite $(\alpha-\mathrm{FeO} \cdot \mathrm{OH})$ by instrumented indentation and molecular dynamics analysis, https://www.researchgate.net/publication/ 257079662_Mechanical_properties_of_magnetite_Fe3O4_hematite_ a-Fe2O3_and_goethite_a-FeOOH_by_instrumented_indentation_and _molecular_dynamics_analysis, 22.06.2017

${ }^{13}$ CEN. EN 12952-3: Water-tube boilers and auxiliary installations, Part 3: Design and calculation for pressure parts of the boiler, 2012 